\title{
Effect of Foreign Metal on Electrochemical Properties of C/LiMnPO Powders Synthesized by Spray Pyrolysis
}

\author{
Atsushi Fujita, Yuichi Suetsugu, Takayuki Kodera and Takashi Ogihara \\ Univ. of Fukui, 3-9-1 Bunkyo, Fukui-shi, Fukui 910-8507 Japan \\ Fax: 81-776-27-8624, e-mail: ogihara@matse.u-fukui.ac.jp
}

\begin{abstract}
Spherical $\mathrm{C} / \mathrm{LiMn}_{1-\mathrm{X}} \mathrm{M}_{\mathrm{X}} \mathrm{PO}_{4}(\mathrm{M}=\mathrm{Mg}, \mathrm{Zn} \mathrm{X}=0,0.01,0.05,0.10)$ precursor powders were successfully prepared by ultrasonic spray pyrolysis. The $\mathrm{C} / \mathrm{LiMn}_{1-\mathrm{X}} \mathrm{M}_{\mathrm{X}} \mathrm{PO}_{4}$ were obtained by heating at $973 \mathrm{~K}$ for 3 hours under argon/hydrogen (5\%) atmosphere. The crystal phases of all samples had an olivine structure with a Pmnb space group and the impurity phase peak was not observed. The average particle size was approximately $0.7 \mu \mathrm{m}$. The electrochemical properties of the $\mathrm{C} / \mathrm{LiMn}_{1-\mathrm{X}} \mathrm{M}_{\mathrm{X}} \mathrm{PO}_{4}$ cathode were estimated by the rechargeable capacity and cycle performance. Electrochemical measurement revealed that the discharge capacity was improved by doping foreign metal such as $\mathrm{Mg}$ and $\mathrm{Zn}$ ion. The first discharge capacity of $\mathrm{C} / \mathrm{LiMn}_{1-\mathrm{X}} \mathrm{Zn}_{\mathrm{X}} \mathrm{PO}_{4}(\mathrm{X}=0.1)$ cathode was approximately $60 \mathrm{mAh} / \mathrm{g}$ at $0.1 \mathrm{C}$. It was steady cycling characteristics.
\end{abstract}

Key words: Spray pyrolysis, $\mathrm{LiMnPO}_{4}$, Olivine, Lithium ion battery, Powders

\section{INTRODUCTION}

Recently, lithium ion batteries are expected as an application for electric vehicles and hybrid electric vehicles. $\mathrm{LiCoO}_{2}$ and $\mathrm{LiMn}_{2} \mathrm{O}_{4}$ have been studied as cathode materials for lithium ion batteries. $\mathrm{LiCoO}_{2}$ has high capacity but it is very expensive and unstable under the high temperature. $\mathrm{LiMn}_{2} \mathrm{O}_{4}$ is low cost and high acceleration voltage. But, it is unstable cycle performance under the high temperature. On the other hand, $\mathrm{LiMnPO}_{4}$ is low cost, relatively high theoretical capacity of $170 \mathrm{mAh} / \mathrm{g}$ and stable cycle performance at high temperature. $\mathrm{LiMnPO}_{4}$ has approximately $4 \mathrm{~V}$ rechargeable regions. However, the electric conductivity of $\mathrm{LiMnPO}_{4}$ is too low to use as cathode material. [1-3]Therefore, $\mathrm{C} / \mathrm{LiMnPO}_{4}$ composites have been often prepared by coating conducting materials such as carbon [4-6], but the electrochemical property of $\mathrm{C} / \mathrm{LiMnPO}_{4}$ is not still improved. Spray pyrolysis is a versatile process that is used to synthesize homogeneous powders [7-9]. In this work, we tried to dope the foreign metal to $\mathrm{C} / \mathrm{LiMnPO}_{4}$ in order to raise the electric conductivity. Spherical $\mathrm{C} / \mathrm{LiMnM}_{\mathrm{X}} \mathrm{PO}_{4}(\mathrm{M}=\mathrm{Mg}, \mathrm{Zn})$ powders were prepared by ultrasonic spray pyrolysis using citric acid as a carbon source. The powders characteristics and the electrochemical properties of $\mathrm{C} / \mathrm{LiMnM}_{\mathrm{X}} \mathrm{PO}_{4}$ were investigated.

\section{EXPERIMENT}

$\mathrm{LiNO}_{3}, \mathrm{Mn}\left(\mathrm{NO}_{3}\right)_{2} \cdot 6 \mathrm{H}_{2} \mathrm{O}$, and $\mathrm{H}_{3} \mathrm{PO}_{4}$ were used as materials for $\mathrm{LiMnPO}_{4}$. $\mathrm{Mg}\left(\mathrm{NO}_{3}\right)_{2} \cdot 6 \mathrm{H}_{2} \mathrm{O}$ and $\mathrm{Zn}\left(\mathrm{NO}_{3}\right) \cdot 9 \mathrm{H}_{2} \mathrm{O}$ were used as a foreign metal for $\mathrm{C} / \mathrm{LiMn}_{1-\mathrm{X}} \mathrm{M}_{\mathrm{X}} \mathrm{PO}_{4}(\mathrm{M}=\mathrm{Mg}, \mathrm{Zn})$. These reagents were dissolved in distilled water. The molar ratio of the element component (Li:Mn:M:P) was set to $1: 1-\mathrm{X}: \mathrm{X}: 1$ $(X=0,0.01,0.05,0.10)$ in the starting solution. The solution concentration was $0.1 \mathrm{~mol} / \mathrm{dm}^{3}$. Citric acid was added as a carbon source. Citric acid concentration was $0.5 \mathrm{~mol} / \mathrm{dm}^{3}$. Starting solution was atomized at a frequency of $1.6 \mathrm{MHz}$ by an ultrasonic nebulizer (HM-1630, Honda electronics). The atomized solution led to the electric furnace at a flow rate of 8 $\mathrm{dm}^{3} /$ min of air carrier gas. The temperature of electric furnace was in the range of 523 to $773 \mathrm{~K}$. $\mathrm{LiMnPO}_{4}$ and $\mathrm{C} / \mathrm{LiMn}_{1-\mathrm{X}} \mathrm{M}_{\mathrm{X}} \mathrm{PO}_{4}(\mathrm{M}=\mathrm{Mg}, \mathrm{Zn}, \mathrm{X}=0,0.01,0.05,0.10)$ precursor powders were continuously collected by cyclon. The precursor powders were calcined at $973 \mathrm{~K}$ for 3 hours in an electric furnace under argon/hydrogen $(5 \%)$ atmosphere. The heating and cooling rates were 5 $\mathrm{K} / \mathrm{min}$. The crystal phases of the precursor powders and calcined powders were observed by powder X-ray diffraction (XRD, XRD-6100, Shimadzu) using $\mathrm{CuK} \alpha$ radiation. The morphology and average particle size of $\mathrm{LiMnPO}_{4}$ and $\mathrm{C} / \mathrm{LiMn}_{1-\mathrm{X}} \mathrm{M}_{\mathrm{X}} \mathrm{PO}_{4}$ were determined with a scanning electron microscope (SEM, JSM-6390, JEOL). The amount of the carbon content was measured by the differential thermogravimetric analysis (DTG, Shimadzu Corporation DTG-60). Reference substance of the measurement was used $\alpha-\mathrm{Al}_{2} \mathrm{O}_{3}$ powders (Shimadzu Corporation). The sample has risen temperature from the room temperature to $1273 \mathrm{~K}$ at a speed of $10 \mathrm{~K} / \mathrm{min}$ in the air atmosphere. The weight changes in exothermic reaction according to heating were measured. The specific surface area was measured by nitrogen gas adsorption (BELSORP-mini2, BEL JAPAN). The specific surface area was evaluated by the BET method. Organic matter of precursor powders and calcined powders were observed by Fourier transform infrared spectroscopy (FT-IR, NICOLETiSO10, Thermo Fisher Scientific) for attenuated total reflection technique. Electric conductivity was determined by LCRmeter. (LCRmeter, KC-537, KOKUYO). The cathode materials were prepared using $80 \mathrm{wt} \%$ calcined powders, $10 \mathrm{wt} \%$ 
(a)

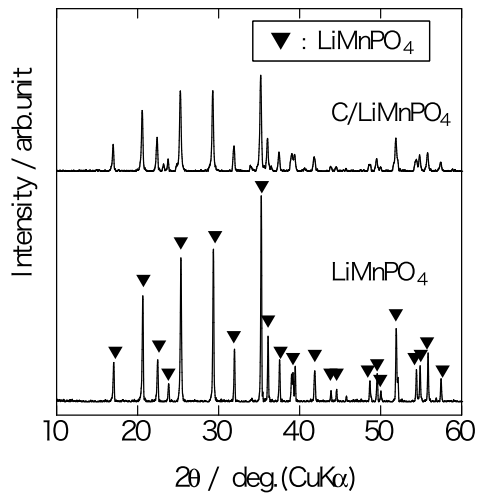

(b)

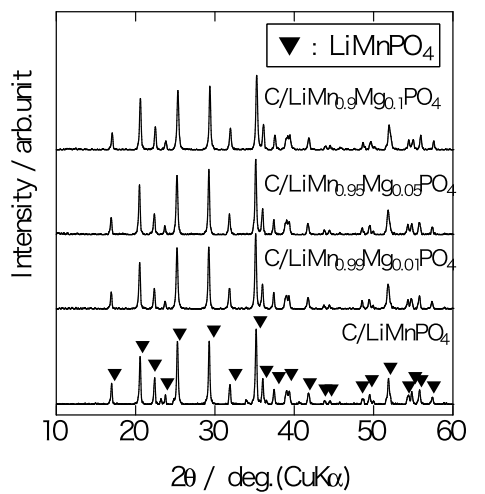

(c)

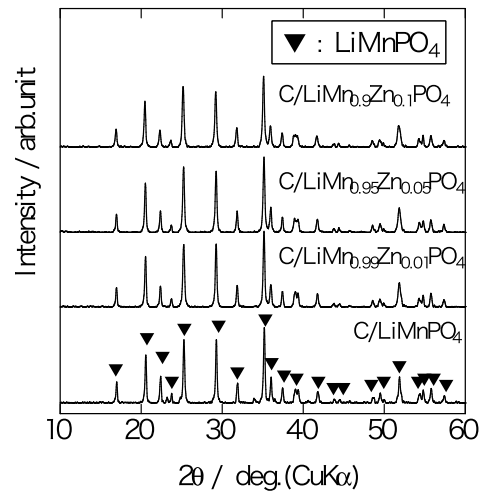

Fig. 1 XRD patterns powders obtained by calcining at $973 \mathrm{~K}$ for 3 hours. (a) $\mathrm{LiMnPO}_{4}$ and $\mathrm{C} / \mathrm{LiMnPO}_{4}$, (b) $\mathrm{C} / \mathrm{LiMn}_{1-\mathrm{X}} \mathrm{Mg}_{\mathrm{X}} \mathrm{PO}_{4}$, and (c) $\mathrm{C} / \mathrm{LiMn}_{1-\mathrm{X}} \mathrm{Zn}_{\mathrm{X}} \mathrm{PO}_{4}$

polyvinylidenefluoride $(\mathrm{PVdF})$ as a binder and $10 \mathrm{wt} \%$ as acetylene black (AB) in N-methyl-2-pyrrolidione (NMP). The slurry was coated on an aluminum foil and then dried at $373 \mathrm{~K}$ for 24 hours. Celgard (Heist, Celgard 2400) was used as a separator. A solution of 1 $\mathrm{mol} / \mathrm{dm}^{3} \mathrm{LiPF}_{6}$ in ethylene carbonate/diethyl carbonate $(\mathrm{EC} / \mathrm{DEC}=1: 1$, Tomiyama Pure Chemical) was used as the electrolyte. Lithium sheet (Honjo Chemical) was used as an anode. The electrochemical properties of $\mathrm{LiMnPO}_{4}$ and $\mathrm{C} / \mathrm{LiMn}_{1-\mathrm{X}} \mathrm{M}_{\mathrm{X}} \mathrm{PO}_{4}$ cathode were examined using a CR2032-type coin cell. These coin cells were set up in globe box under argon atmosphere. The rechargeable capacity and cycle performance of the $\mathrm{LiMnPO}_{4}$ and $\mathrm{C} / \mathrm{LiMn}_{1-\mathrm{X}} \mathrm{M}_{\mathrm{X}} \mathrm{PO}_{4}$ cathode were measured with a battery tester (Hosen, BTS2004) between 2.0 and $4.6 \mathrm{~V}$ at $0.01 \mathrm{C}$ and $0.1 \mathrm{C}$.

\section{RESULT AND DISCUSSION}

3.1 Powder characteristics

The crystal phase and crystallinity of precursor powders, $\mathrm{LiMnPO}_{4}$, and $\mathrm{C} / \mathrm{LiMn}_{1-\mathrm{X}} \mathrm{M}_{\mathrm{X}} \mathrm{PO}_{4}$ powders were identified by XRD. Figure 1 shows XRD patterns of $\mathrm{LiMnPO}_{4}$ and $\mathrm{C} / \mathrm{LiMn}{ }_{1-\mathrm{X}} \mathrm{M}_{\mathrm{X}} \mathrm{PO}_{4}$ powders obtained by calcining at $973 \mathrm{~K}$ for 3 hours and precursor powders. The crystal phases of calcining at $973 \mathrm{~K}$ for 3 hours

(a)

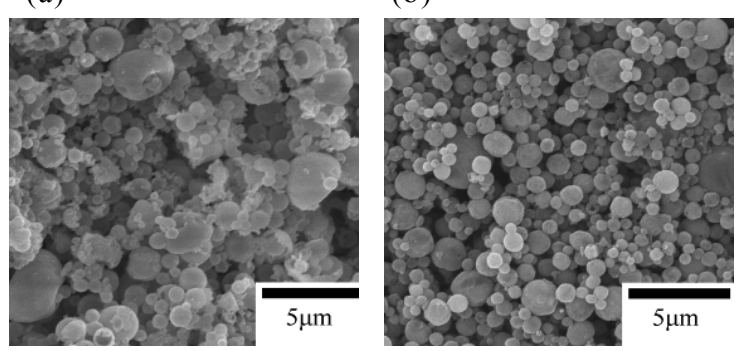

Fig. 2 SEM photographs of (a) $\mathrm{LiMnPO}_{4}$ and (b) $\mathrm{C} / \mathrm{LiMnPO}_{4}$ samples had an olivine structure with a Pmnb space group. The impurity phase peak was not observed. On the other hand, precursor powders were not uncrystallized. XRD patterns showed the crystallinity of $\mathrm{LiMnPO}_{4}$ was higher than that of $\mathrm{C} / \mathrm{LiMnPO}_{4}$. Therefore, no evidence for diffraction peaks for crystalline carbon appeared in the diffraction patterns; this indicates that the carbon generated from ciyric acid was amorphous carbon and that the presence of carbon did not influence the crystal structure of $\mathrm{LiMnPO}_{4}$. XRD patterns showed other phases were not observed regardless of amount of foreign metal.

Figure 2 shows the SEM photographs of $\mathrm{LiMnPO}_{4}$ powders obtained by calcining at $973 \mathrm{~K}$ for 3 hours under argon/hydrogen (5\%) atmosphere. The $\mathrm{LiMnPO}_{4}$ powders had irregular particle morphology. In contrast, $\mathrm{C} / \mathrm{LiMnPO}_{4}$ powders had spherical particle morphology. The average particle size of $\mathrm{LiMnPO}_{4}$ was approximately $0.8 \mu \mathrm{m}$, and that of $\mathrm{C} / \mathrm{LiMnPO}_{4}$ was approximately $0.7 \mu \mathrm{m}$. The average particle size of $\mathrm{C} / \mathrm{LiMnPO}_{4}$ was smaller than that of $\mathrm{LiMnPO}_{4}$.

Figure 3 shows infrared absorption spectrum of precursor powders and $\mathrm{C} / \mathrm{LiMnPO}_{4}$ powders by FT-IR. $\mathrm{C} / \mathrm{LiMnPO}_{4}$ Precursor powders were observed the absorption spectrum of the $\mathrm{H}-\mathrm{O}-\mathrm{H}$ stretching was

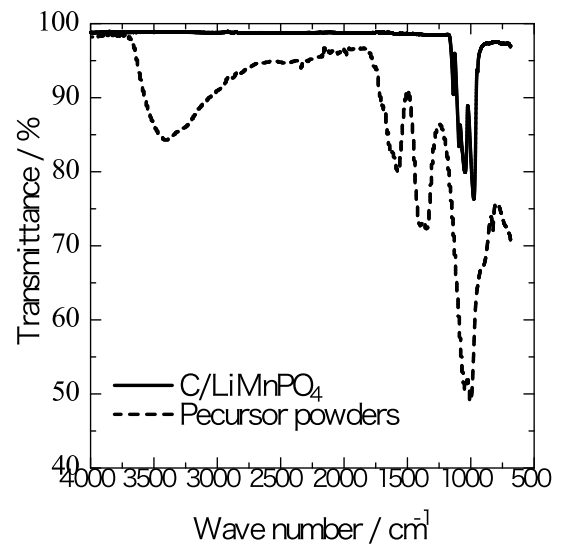

Fig.3 FT-IR absorbance spectra of $\mathrm{C} / \mathrm{LiMnPO}_{4}$ and precursor powders 
(a)

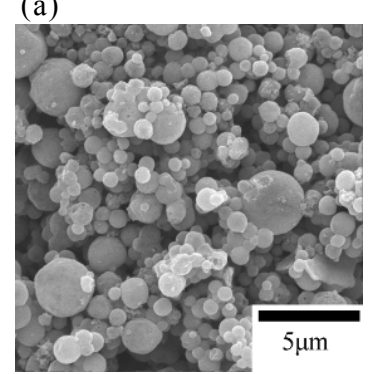

(d)

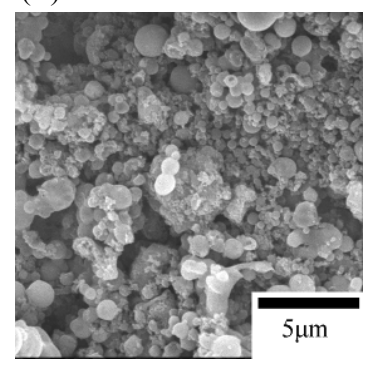

(b)

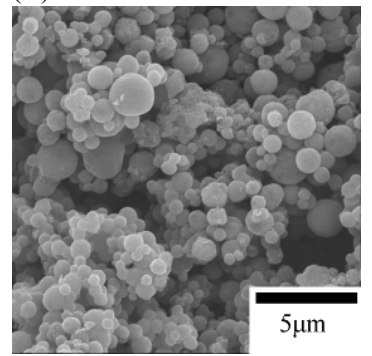

(e)

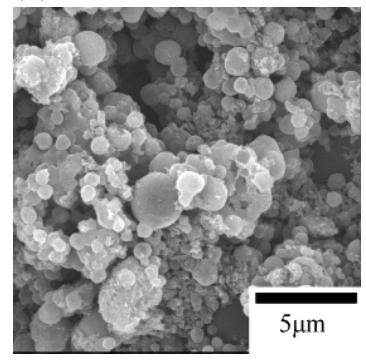

(c)

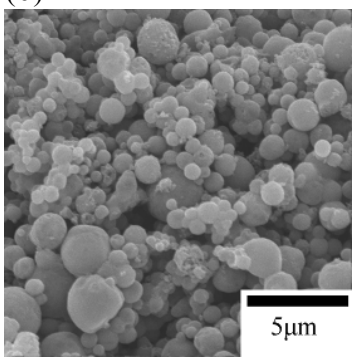

(f)

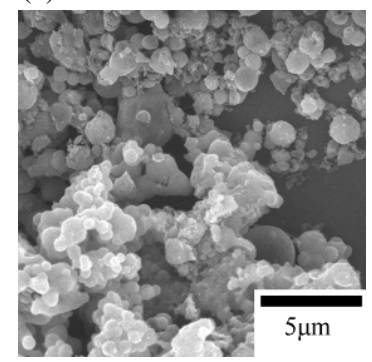

Fig. 4 SEM photographs of $\mathrm{C} / \mathrm{LiMn}_{1-\mathrm{X}} \mathrm{M}_{\mathrm{X}} \mathrm{PO}_{4}$ powders (a) $\mathrm{M}=\mathrm{Mg}, \mathrm{X}=0.01$, (b) $\mathrm{M}=\mathrm{Mg}, \mathrm{X}=0.05$, (c) $\mathrm{M}=\mathrm{Mg}, \mathrm{X}=0.1$, (d) $\mathrm{M}=\mathrm{Zn}, \mathrm{X}=0.01$, (e) $\mathrm{M}=\mathrm{Zn}, \mathrm{X}=0.05$, and (f) $\mathrm{M}=\mathrm{Zn}, \mathrm{X}=0.1$.

observed the vicinity of $3500 \mathrm{~cm}^{-1}$. The absorption spectrum that has roots in the nitrate was observed in the vicinity of $1400 \mathrm{~cm}^{-1}$. It is found that the water of crystallization and the nitrate exist in $\mathrm{C} / \mathrm{LiMnPO}_{4}$ precursor powders. On the other hand, absorption spectrums were of these not observed at $\mathrm{C} / \mathrm{LiMnPO}_{4}$. $\mathrm{C} / \mathrm{LiMnPO}_{4}$ precursor powder and $\mathrm{C} / \mathrm{LiMnPO}_{4}$ was observed intense $\mathrm{P}-\mathrm{O}$ stretching bands the vicinity of $1100 \mathrm{~cm}^{-1}$. It is found that $\mathrm{PO}_{4}{ }^{3-}$ exists in $\mathrm{C} / \mathrm{LiMnPO}_{4}$ precursor and $\mathrm{C} / \mathrm{LiMnPO}_{4}$.

Figure 4 shows the SEM photographs of $\mathrm{C} / \mathrm{LiMn}_{1-\mathrm{X}} \mathrm{M}_{\mathrm{X}} \mathrm{PO}_{4}$ powders obtained by calcining at 973 $\mathrm{K}$ for 3 hours under argon/hydrogen $(5 \%)$ atmosphere. The $\mathrm{C} / \mathrm{LiMn}_{1-\mathrm{X}} \mathrm{Zn}_{\mathrm{X}} \mathrm{PO}_{4}$ powders had irregular particle morphology. In contrast, $\mathrm{C} / \mathrm{LiMn}_{1-\mathrm{X}} \mathrm{Mg}_{\mathrm{X}} \mathrm{PO}_{4}$ powders had spherical particle morphology. The average particle size of $\mathrm{C} / \mathrm{LiMn}_{1-\mathrm{X}} \mathrm{M}_{\mathrm{X}} \mathrm{PO}_{4}$ was from 0.7 to $0.8 \mu \mathrm{m}$. The average particle sizes of all samples were approximate.

The specific surface area of $\mathrm{LiMnPO}_{4}$ and $\mathrm{C} / \mathrm{LiMn}_{1-\mathrm{X}} \mathrm{M}_{\mathrm{X}} \mathrm{PO}_{4}$ powders were observed by $\mathrm{BET}$ method. The specific surface area of $\mathrm{LiMnPO}_{4}$ powders were $2.0 \mathrm{~m}^{2} / \mathrm{g}$. On the other hand $\mathrm{C} / \mathrm{LiMn}_{1-\mathrm{X}} \mathrm{M}_{\mathrm{X}} \mathrm{PO}_{4}$ powders were approximately $30 \mathrm{~m}^{2} / \mathrm{g}$. The specific surface was increased by carbon doping. $\mathrm{C} / \mathrm{LiMnPO}_{4}$ and $\mathrm{C} / \mathrm{LiMn}_{1-\mathrm{X}} \mathrm{Mg}_{\mathrm{X}} \mathrm{PO}_{4}$ powders were spherical morphology; $\mathrm{C} / \mathrm{LiMn}_{1-\mathrm{X}} \mathrm{Zn}_{\mathrm{X}} \mathrm{PO}_{4}$ powders had irregular morphology. But, the specific surface area of these were approximate.

As results of DTG, $\mathrm{LiMnPO}_{4}$ was no weight loss and not identify exothermic or endothermic reaction. On the other hand, the weight loss of $\mathrm{C} / \mathrm{LiMnPO}_{4}$ and $\mathrm{C} / \mathrm{LiMn}_{1-\mathrm{X}} \mathrm{M}_{\mathrm{X}} \mathrm{PO}_{4}$ was $10 \mathrm{wt} \%$ and exothermic reaction by combustion of the carbon. The temperature was approximately $573 \mathrm{~K}$ from $873 \mathrm{~K}$. The carbon content was assumed to $10 \mathrm{wt} \%$. The addition of foreign metal did not influence the carbon content.

\subsection{Electrochemical properties}

Figure 5 showed the first charge and discharge capacities of $\mathrm{LiMnPO}_{4}$ and $\mathrm{C} / \mathrm{LiMn}_{1-\mathrm{X}} \mathrm{M}_{\mathrm{X}} \mathrm{PO}_{4}(\mathrm{M}=\mathrm{Mg}$, $\mathrm{Zn}, \mathrm{X}=0,0.10$ ) cathodes at a rate of $0.1 \mathrm{C}$. The first discharge capacity of $\mathrm{LiMnPO}_{4}$ and $\mathrm{C} / \mathrm{LiMnPO}_{4}$ were 2 $\mathrm{mAhg}^{-1}$ and $16 \mathrm{mAhg}^{-1}$, respectably. The efficiency of rechargeable capacity of $\mathrm{LiMnPO}_{4}$ and $\mathrm{C} / \mathrm{LiMnPO}_{4}$ cathodes were $85 \%, 73 \%$, respectably. The electrical conductivity of $\mathrm{LiMnPO}_{4}$ was $10^{-9} \mathrm{~S} / \mathrm{cm}$. On the other hand that of $\mathrm{C} / \mathrm{LiMnPO}_{4}$ was $10^{-5} \mathrm{~S} / \mathrm{cm}$. The addition of carbon $\mathrm{LiMnPO}_{4}$ led to the improvement of the electric conductivity of $\mathrm{LiMnPO}_{4}$. However the discharge capacity of $\mathrm{C} / \mathrm{LiMnPO}_{4}$ is low. On the other hand, the electrical conductivity of $\mathrm{C} / \mathrm{LiMn}_{1-\mathrm{X}} \mathrm{Mg}_{\mathrm{X}} \mathrm{PO}_{4}$ and $\mathrm{C} / \mathrm{LiMn}_{1-\mathrm{X}} \mathrm{Zn}_{\mathrm{X}} \mathrm{PO}_{4}$ were approximately $10^{-4} \mathrm{~S} / \mathrm{cm}$. The doping foreign metal led to the improvement of the electric conductivity of $\mathrm{C} / \mathrm{LiMnPO}_{4}$. The first discharge capacity of $\mathrm{C} / \mathrm{LiMn}_{0.9} \mathrm{Mg}_{0.1} \mathrm{PO}_{4}$ was $45 \mathrm{mAhg}^{-1}$ and the

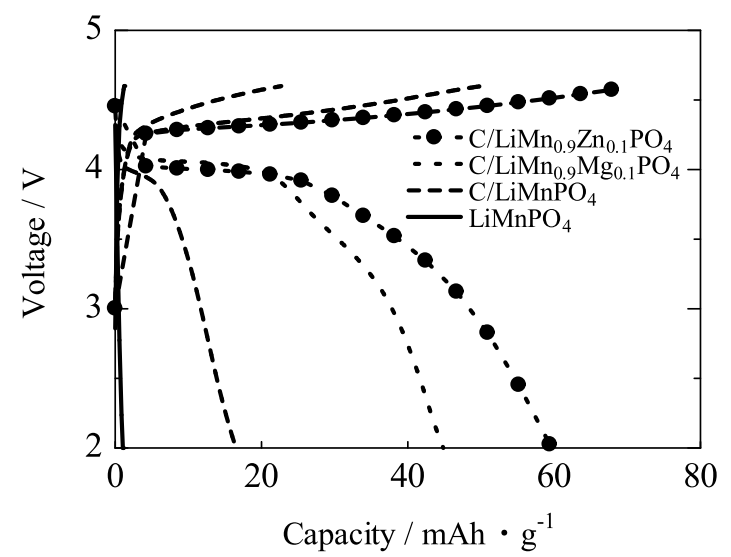

Fig.5 First charge and discharge curves 
(a)

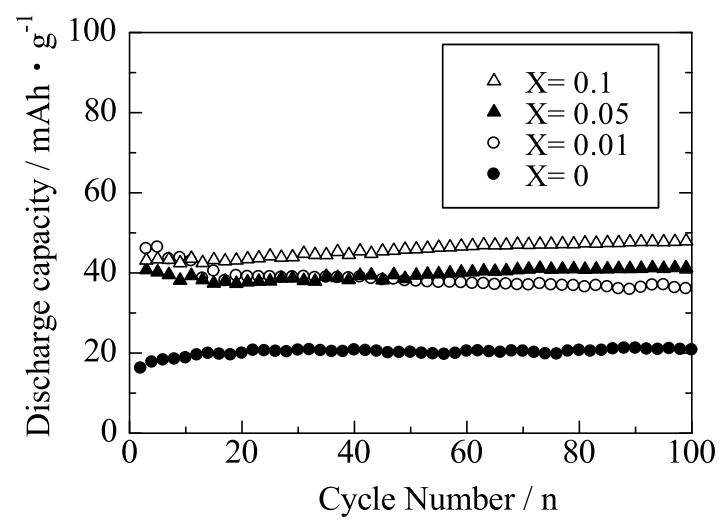

(b)

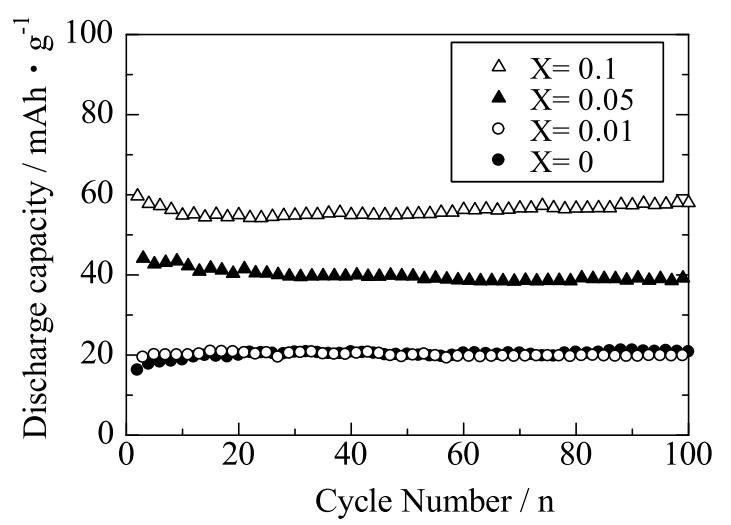

Fig.6 Cycle performance of (a) $\mathrm{C} / \mathrm{LiMn}_{1-\mathrm{X}} \mathrm{Mg}_{\mathrm{X}} \mathrm{PO}_{4}$ and (b) $\mathrm{C} / \mathrm{LiMn}_{1-\mathrm{X}} \mathrm{Zn}_{\mathrm{X}} \mathrm{PO}_{4}$

efficiency of rechargeable capacity was $90 \%$. The first discharge capacity of $\mathrm{C} / \mathrm{LiMn}_{0.9} \mathrm{Zn}_{0.1} \mathrm{PO}_{4}$ was 60 $\mathrm{mAhg}^{-1}$ and the efficiency of rechargeable capacity was $84 \%$. Figure 6 (a) showed the cycle performance of $\mathrm{LiMnPO}_{4}$ and $\mathrm{C} / \mathrm{LiMnPO}_{4}$ at rate of $0.01 \mathrm{C}$ and $0.1 \mathrm{C}$ by $298 \mathrm{~K}$. The discharge capacity of $\mathrm{LiMnPO}_{4}$ and $\mathrm{C} / \mathrm{LiMnPO}_{4}$ were $1 \mathrm{mAhg}^{-1}$ and $16 \mathrm{mAhg}^{-1}$ at $0.1 \mathrm{C}$, respectably. The discharge capacity of $\mathrm{LiMnPO}_{4}$ and $\mathrm{C} / \mathrm{LiMnPO}_{4}$ were $2 \mathrm{mAhg}^{-1}$ and $45 \mathrm{mAhg}^{-1}$ at $0.01 \mathrm{C}$, respectably. Figure 6 (b) and (c) showed the cycle performance of $\mathrm{C} / \mathrm{LiMn}_{1-\mathrm{X}} \mathrm{M}_{\mathrm{X}} \mathrm{PO}_{4}(\mathrm{M}=\mathrm{Mg}, \mathrm{Zn}, \mathrm{X}=0$, $0.01,0.05,0.10)$ at a rate of $0.1 \mathrm{C}$ by $298 \mathrm{~K}$. The discharge capacity of $\mathrm{C} / \mathrm{LiMn}_{1-\mathrm{X}} \mathrm{Mg}_{\mathrm{X}} \mathrm{PO}_{4}$ was increased, as the amount of $\mathrm{Mg}$-dope was increased. After 100 cycles, $97 \%$ of the first discharge capacity was maintained at the rate of $0.1 \mathrm{C}$. The discharge capacity of $\mathrm{C} / \mathrm{LiMn}_{1-\mathrm{X}} \mathrm{Zn}_{\mathrm{X}} \mathrm{PO}_{4}$ was increased, as the amount of $\mathrm{Zn}$-dope was increased. After 100 cycles, $97 \%$ of the first discharge capacity was maintained at the rate of 0.1 C. The discharge capacity of $\mathrm{C} / \mathrm{LiMn}_{1-\mathrm{X}} \mathrm{M}_{\mathrm{X}} \mathrm{PO}_{4}(\mathrm{M}=$ $\mathrm{Mg}, \mathrm{Zn}$ ) powders derived from citric acid was found to result in stable cycle performance, and the results demonstrated improved electrical conductivity with carbon and metal material doping.

\section{CONCLUSION}

$\mathrm{C} / \mathrm{LiMn}_{1-\mathrm{X}} \mathrm{M}_{\mathrm{X}} \mathrm{PO}_{4} \quad(\mathrm{M}=\mathrm{Mg}, \mathrm{Zn})$ precursor powders were successfully prepared by ultrasonic spray pyrolysis using aqueous solution with citric acid. XRD revealed that the diffraction peak of all sample were olivine structure. The discharge capacity of $\mathrm{C} / \mathrm{LiMnPO}_{4}$ led to the improvement of the $\mathrm{Mg}$ and $\mathrm{Zn}$ doped. The discharge capacity of $\mathrm{C} / \mathrm{LiMn}_{1-\mathrm{X}} \mathrm{Zn}_{\mathrm{X}} \mathrm{PO}_{4}$ was increasing $\mathrm{Zn}$-doped volume. From electrochemical measurement, the discharge capacity of $\mathrm{LiMn}_{0.9} \mathrm{Zn}_{0.1} \mathrm{PO}_{4}$ was 60 $\mathrm{mAh} / \mathrm{g}$ at $0.1 \mathrm{C}$. After 100 cycles, $97 \%$ of the initial discharge capacity was maintained.

\section{ACKNOWLEDGEMENT}

This work was supported by Development of an Electric Energy Storage System for Grid-connection with New Energy Resources in New Energy and Industrial Technology Development Organization.

\section{REFERENCES}

[1] A.K.Padhi, K.S.Nanjundaswamy, J.B.Goodenough, J. Electrochem. Soc., 144, 1188. (1997)

[2] J.D. Wilcox, M.M. Doeff, M.Marcinek, R.Kostecki, J. Electrochem. Soc., 154, A389. (2007)

[3] S.L.Bewlay, K.Konstantinov, G.X.Wang, S.X.Dou, H.K.Liu, Mater.Lett. , 58, 1788. (2004)

[4] Thierry Drezen, Nam-Hee Kwon, Paul Bowen, Ivo Teerlinck, Motoshi Isono, Ivan Exnar, J.Power Sources, 174, 949 (2007)

[5] T. Shiratsuchi, S. Okada, T. Doi, J. Yamaki, Electrochimica Acta, 54, 3154 (2009)

[6] M.R. Yang, T.H. Teng, S.H. Wu, J. Power Sources, 159, 307 (2006) .

[7] T. Ogihara, N. Ogata, K. Katayama, Y. Azuma, Electrochemistry, 68, 162 (2000).

[8] K. Myojin, T. Ogihara, N. Ogata, N. Aoyagi, H. Aikiyo, T. Ookawa, S. Omura, M. Yanagimoto, M. Uede, T. Oohara, Adv. Powder Technol., 15, 397 (2004) .

[9] I. Taniguchi, D. Song, M. Wakihara, J. Power Sources, 109, 333 (2002).

(Received January 25, 2010; Accepted July 1, 2010) 